\title{
Psalms in the Early Modern World, edited by Linda P. Austern, Kari B. McBride, and David L. Orvis
}

Burlington: Ashgate, 20I I | xxiii +385 pages | ISBN: 978-I4094-2282-2 (hardback) £65.00

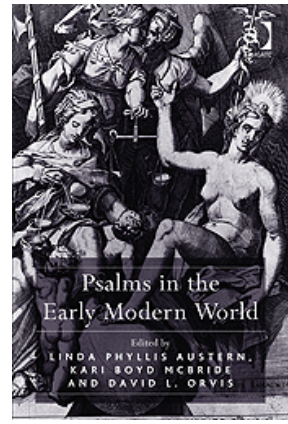

Psalms in the Early Modern World makes a strong and persuasive argument that no text offers a better lens than the Biblical Psalter into the circulation of religious beliefs, political ideas, and musical practices of the Atlantic world during the sixteenth and seventeenth centuries. "Arguably the most influential biblical book of the early modern period," the editors assert, "the Psalms traveled throughout Europe and across the Atlantic, reappearing in religious and secular works by groups who derided or simply disregarded one another. That they were reinterpreted and rewritten to accommodate such vastly different worldviews suggests not only that the Psalms formed the heart of both public and private devotions for Jews and Christians of all denominations, but also that they played a central role in mediating cultural and political conflicts" (33).

Part I, "Communities of Worship," explores the role psalms played in fostering and maintaining faith communities amid the harrowing circumstances of the Reformation and Counter-Reformation. Richard Freedman focuses on how French composer Simon Goulart in his Cinquante pseaumes deployed contrafacta (substituting French psalm translations for the worldly texts set by composers like Orlando di Lasso), which recast worship for Calvinist Huguenots. "Just as many of these believers were obligated to seek refuge in places like London, La Rochelle, or Geneva, and to inscribe spiritual meanings in their new physical surroundings," he writes, "they also sought spiritual refuge in the metaphorical spaces of beloved secular music by Lasso and other masters of the day." (52) Roger Bray focuses on the obverse phenomenon, William Byrd's settings of metrical psalms for fellow Catholics in England in the late sixteenth century, an era when religious recusants like Edmund Campion were being executed. A third chapter, by Linda P. Austern, highlights the ways in which psalm-singing allowed Anglican women of diverse social backgrounds to escape gender constraints imposed by men and local parish churches. "Women from all social strata and a range of religious and 
political affiliations from the late sixteenth century to the Restoration clearly had access to a variety of musical settings of psalms, as well as to a range of instruments and training with which to enhance them," she concludes (I I4). A fourth essay, by Joanne van ver Woude, explores the production of the Bay Psalm Book, the first English-language book published in North America, as an act of colonial self-fashioning, charting a middle way between the dominance of Sternhold and Hopkins and the more musically refined Ainsworth Psalter carried to New England by the Pilgrims. "As a text of immigration," van der Woude asserts, "the psalter constitutes the Puritans' first conscious self-articulation within the transcultural structure of British imperialism" (I34).

Part 2, "Contested Grounds of Authority," offer three case studies of how interpreters drew on the Psalms to adjudicate disputes about scriptural exegesis, proper penance, and the nature of monarchic rule. Jamie H. Ferguson challenges the claim that Miles Coverdale's use of biblical paraphrase rather than Latin translation in his groundbreaking psalter reflected his ignorance of Latin; rather, "his use of a paraphrase for his first Psalter and his series of Psalters taken as a group suggest, despite Protestant promotion of the unique authority of sola scriptura, that such claims can only ever be plural and complex" (I 54). Clare Costley King'oo shows how Sir Thomas Wyatt's posthumously published translations of penitential psalms were released by Edwardian reformers to buttress their campaign against traditional doctrines about penance. "The first evangelicals might have rejected penance as a sacrament," King'oo concludes, "but, as the Edwardian edition of Wyatt's paraphrase reveals, that made it all the more important for them to develop a model of what ... 'ryghtfull penitence' should be” (I74). James F. Melvin's essay pivots to Catholic Spain, where Juan de Avila's Audi, filia deployed verses from Ps 44 to construct a model of "nuptial spirituality" that, while underscoring the importance of a spiritual director, allowed devout believers, especially women, to carve out some minimal space beyond the grip of clerical hegemony. Carol V. Kaske investigates a more overt use of the Royal Psalms to buttress monarchic authority: Edmund Spenser's tracing in The Shepheardes Calendar and Faerie Queene of the Tudor line back to King David. "In political terms, by portraying Elisabeth through Una as both Sapience and the True Church, Spencer vigorously supports her claim to be supreme governor of the English Church," she writes. "Through all his Christological rhetoric, he gives back to her in myth, mysticism, and allegory that likeness to Christ as the head of the church which she modestly refused in reality" (215). 
Several fundamental questions animate Part 3, "Psalmic Voice(s)": "First, whose voice do we hear in the Psalms? Is it God's? David's? The poet's? And second, what is the origin of their power? Is it the text itself? The music that accompanied it? The commingling of the two?" (3I) Tracing the reception history of psalm translations produced by Mary Sidney, Countess of Pembroke, Margaret P. Hannay demonstrates how these texts straddled the line between literature and liturgy. "Devout readers could sing her rime royal rendition of Psalm 5 I, utilize her Psalmes for spiritual instruction, or even use them to replace the Coverdale Psalms for worship in Morning and Evening Prayer" (233). Just as Mary Sidney collaborated with her brother Philip on psalm translations, Elisabeth Sophie's partnership with her brother Louis Chéron was even more extraordinary: a Catholic, Elisabeth was responsible for the French and Latin translations while her Huguenot brother produced the illustrations. Shifting from the visual to the sonic, Don Harrán examines early modern debates over the power of the psalms by focusing on the theorizing of seventeenth-century composer Angelo Berardi. Oscillating between the rival theories of musica practica (the music itself) and music speculativa (its extramusical associations), Berardi simultaneously attributed "the effect of metrical psalms on the auditor as residing in the construction of the instrument" as well as "to the various emanations in theosophical Kabbalah" (32).

The book's final section, "Generic Innovation," is also the shortest, with just two chapters. Penny Granger reconstructs the world of the English N-Town Play of the mid-fifteenth through sixteenth centuries- "a cycle of plays telling the scriptural story from creation to doom, on to which have been grafted two passion plays and two hagiographical plays about the Virgin Mary" (300). Spectators were exposed to both psalm translations and also demonstrations through the character of the Virgin Mary of how such psalms might serve as prayer aids. "Not just the Archangel Gabriel but the Psalter itself gives the Virgin the authority to issue a three-dimensional invitation to the audience to pick up the book, emulate her learning and join her in her devotions, and stay faithful to her son in death" (3 I 4). Returning to the transatlantic exchange discussed in van der Woude's chapter, John F. Schwaller offers a fascinating reading of sixteenth-century missionary to New Spain Fr. Bernardino de Sahagún's Psalmodia christiana. Realizing the limitations of catechisms and confessional guides, he injected Christian beliefs into traditional Nahuatl art forms like song. "In the Psalmodia one can see the vestiges of the pre-Columbian verse forms upon which the new Chris- 
tian songs were built," Schwaller concludes. "Yet one can also appreciate the Christian models upon which Sahagún also drew in creating his work" (332).

Although the editors' Introduction makes a valiant effort to sketch out an overarching framework for the collection, this is not the sort of book from which a reader easily extracts a unifying thread, other than that the reception history of the Hebrew Psalter during pivotal centuries in the development of the modern West was extremely active and complex. Readers interested in an even more broadly defined assessment of the Psalter's reception history, this one spanning millennia, might want to consult the new collection edited by Susan Gillingham, Jewish and Christian Approaches to the Psalms: Conflict and Convergence, just out from Oxford University Press.

David W. Stowe

Michigan State University 